\title{
Performances and Genetic Parameters Estimation of Yield and Yield Related Traits in Sweet Corn Inbred Lines Selected for Better Adaptation to Organic Cropping System
}

\author{
Mohammad Chozin ${ }^{\mathrm{a},}$, Sigit Sudjatmiko ${ }^{\mathrm{a}}$, Zainal Muktamar ${ }^{\mathrm{a}}$, Nanik Setyowati ${ }^{\mathrm{a}}$, Fahrurrozi Fahrurrozi ${ }^{\mathrm{a}}$ \\ ${ }^{a}$ Faculty of Agriculture, University of Bengkulu, Kandang Limun, Bengkulu 38371A, Indonesia \\ E-mail: "mchozin@unib.ac.id
}

\begin{abstract}
Limited number of sweet corn varieties specifically bred for organic cropping system has brought about the organic sweet corn growers use hybrid varieties supposedly grown under high agrochemical inputs cropping system. The objective of the present study was to evaluate the performance of sweet corn inbred lines and to estimate the genetic parameters as to the development of varieties suitable for organic cropping systems. Eight inbred lines of S5generation previously selected for yield and adaptability to organic conditions were evaluated in a randomized block design with seven replications. Performances and genetic parameter estimation were addressed to plant height, the number of leaves, stalk diameter, ear length, ear diameter, kernel row number, kernel number per row, and ear yield per plant. Significant variations were found among the inbred lines for all traits studied. Similar features were also found within the inbred line, except stalk diameter showed non-significant within-line variation. Evaluation of mean values indicated that CAPS 2 exhibited the best plant growth performances and produced reasonably high ear yield. CAPS 5 produced the highest ear yield along with superior ear length, ear diameter, and kernel row number. Broad sense heritability $\left(h^{2}{ }_{B}\right)$ were ranged from low to moderate with the higher estimates found on ear length $(0.43)$ and ear yield per plant $(0.40)$. Based on the estimates of genetic advance as percent of the population mean (GAM), moderate improvement can be expected from ear length $(\mathbf{1 3 . 3 7 \%})$ and ear yield per plant $(\mathbf{2 0 . 8 6 \%})$ by selecting the top $5 \%$ of the inbred line populations.
\end{abstract}

Keywords - sweet corn inbred lines; organic cropping system; heritability; genetic advance.

\section{INTRODUCTION}

The recent increase in consumer concern on food quality, food health, and environmental sustainability to a large extent has contributed to a substantial development in the organic sweet corn production system. Some studies have been conducted to provide scientific background for attaining success in crop production, including the use of organic inputs and crop management. A variety of organic materials has been claimed to be potential alternatives to inorganic fertilizers in providing plant nutrients for sweet corn [1]-[3]. Similarly, there are some technologies for coping with pest, disease, and weed problems suited for organic crop production [4]-[6]. Apart from these facts, the development of organic sweet breeding is still in its infancy [7], [8].

Breeding of sweet corn for developing varieties best suited for organic production must deal with multiple objectives to meet both the growers' and consumers' demands. For the growers, the varieties for organic production should have comparable ear yield to varieties designed for conventional production. Moreover, morphological characteristic of ear and kernel, as well as chemical composition of the kernel is important to the consumers and industrial processing [9], [10]. For these reasons, selection and evaluation during inbred lines development should be carried out under organic environments to facilitate an objective judgment in each step of the breeding program.

The organic cropping system is characterized by avoidance of using of artificial fertilizers, synthetic pesticides, growth hormones, and genetically modified organism in the crop production [11]. Such system implies that plant selection under organic conditions is challenging as the plant performances to a large extent are dictated by limited nutrients availability in the soil, weed competition, and pests and diseases suppression [12]. Consequently, the plant's selection under organic cropping system during the inbred development should be addressed to full exploitation of genetic potential existing in the breeding population.

Like other open pollinated crops, hybrid varieties are the targeted products of sweet corn breeding program and combining ability (CA) test plays an essential step in identifying potential combiners and hybrid combinations. CA test is commonly carried out at the earlier generation of inbreeding, vis., $S_{3}$, or $S_{4}$ generation [13]. However, such a 
test involves considerable effort and resources commonly practiced by large seed companies. Therefore, delayed CA tests until later generations are not uncommon with the assumption that continuing selection on inbred line per se for the traits with additive inheritance till $S_{5}$ or $S_{6}$ generation would reduce the number of inbred lines should be tested for CA [14]. This study aims to evaluate the variability of eight sweet corn inbred lines that previously selected under an organic cropping system. This study also aims to estimate the genetic parameters as to the determination of inheritance modes of yield and yield corresponding traits and to assess the progress that could be expected from the selection practices.

\section{MATERIALS AND METHOD}

\section{A. Location and Characteristic of the Experimental Site}

The experiment was run on an organic research land at Sukamarga, Rejang Lebong Regency, Bengkulu Province, Indonesia (Longitude. 102 $30^{\prime}$ E., Latitude. $3^{\circ} 29^{\prime} \mathrm{S}$., Altitude 618 m.a.s.l,). The soil type is inceptisol, with soil $\mathrm{pH}=5.6$. The site had been used for organic vegetable production in two consecutive years before the current experiment.

\section{B. Plant Materials and Experimental Design}

Eight sweet corn inbred lines (CAPS 2, CAPS 3, CAPS 5, CAPS 15, CAPS 17A, CAPS 17B, CAPS 22, and CAPS 23) were used in this experiment. The lines were the fifth generation of selfing $\left(\mathrm{S}_{5}\right)$, as shown in Table 1 , and developed through selection program under organic cropping management. Each line was randomly allocated to the experimental units according to a randomized complete block design with seven replications. Seeds from each line were shown in a double row plot of $4 \mathrm{~m}$ long with a plant-to-plant distance of $20 \mathrm{~cm}$ and the rows-to-row distance of $70 \mathrm{~cm}$.

TABLE I

THe Pedigree of INBRED Lines UsEd In THE StUdy

\begin{tabular}{|c|l|c|}
\hline No. & Line & Pedigree \\
\hline 1 & CAPS 2 & BS - 1-2-1-1-2 \\
\hline 2 & CAPS 3 & GD -2-2-1-1-2 \\
\hline 3 & CAPS 5 & MTO C-2-1-1-3 \\
\hline 4 & CAPS 15 & SB-1-5-1-4-2 \\
\hline 5 & CAPS 17A & SG -2-1-1-2-1 \\
\hline 6 & CAPS 17B & SG -2-4-1-3--1 \\
\hline 7 & CAPS 22 & BM -3-3-1-3-2 \\
\hline 8 & CAPS 23 & SI -2-1-1-8-1 \\
\hline
\end{tabular}

\section{Crop Management}

A week before sowing, the land was prepared manually using hoes, and cow manure at 15 -ton $\mathrm{ha}^{-1}$ was added to the soil as the basal fertilizer. Additional fertilizer was applied by spraying the plants four times during the plant growth period with two weeks interval using liquid organic fertilizer [15], [16]. The soil of each plant row was risen at 4 WAP (weeks after planting) using the inter-row soil. Plant water was supplied as necessary from the adjacent irrigation facility. No agrochemical products were applied during the experimentation. Similarly, no control measure was taken for pest and disease as their infestations were negligible. Weeds were controlled manually using hoes. Ears were thinned two days following pollination to leave a single ear per plant. Ears were harvested at 30 days after silking as the husk had turned dark green, silks turned dark brown, and kernels fully developed and oozed milky sap when pinched with fingernails.

\section{Measurements and data collection}

Five plant samples were randomly selected from each plot to produce the experimental data. The data were collected for plant height, the number of leaves, stalk diameter, ear length, ear diameter, kernel-row number, kernel number per row, and ear yield per plant (weight of ear with husk per plant). Plant height was measured from the soil surface to the plant tip. The number of leaves was counted from all leaves arisen on the plant, including the flag leaf. Ear length was measured from the basal to the tip of the husk. Ear diameter was measured as the girth of the ear. Kernel-row-number was the number of kernel-row formed in the ear. Kernel number per row was measured as the average number of kernels formed in each kernel row. Ear yield was measured on the single plant by weighing the produced ear, including the husk, on a digital balance.

\section{E. Data analysis}

The collected data were subjected to analysis of variance to reveal the significant variations among and within the inbred lines on the traits studied, following the procedure as described by [17] with the linear additive model for the analysis as:

$$
\mathrm{Y}_{\mathrm{ijk}}=\mu+\tau_{\mathrm{i}}+\rho_{\mathrm{j}}+\tau \rho_{\mathrm{ij}}+\varepsilon_{\mathrm{ijk}}
$$

( $i=1,2, \ldots, 8 ; j=1,2, \ldots, 7 ; k=1,2, \ldots, 5$ )

where $\mathrm{Y}_{\mathrm{ijk}}$ : the observation made on the $\mathrm{k}^{\text {th }}$ individual plant in $\mathrm{i}^{\text {th }}$ line row and jth block. $\mu$ : the overall mean; $\tau \mathrm{i}$ : the fixed effect of the $i^{\text {th }}$ line; $\beta \mathrm{j}$ is the effect of the $\mathrm{j}^{\text {th }}$ block, a random variable with mean zero and variance $\sigma_{\beta}^{2} ; \tau \beta_{\mathrm{ij}}$ : the experimental error, measuring the variation among plant samples within the line. The genetic parameters were estimated from the mean-squares [18] as given below in Table 2:

TABLE II

GENETIC PARAMETERS

\begin{tabular}{|l|c|c|c|c|}
\hline Source & $\begin{array}{l}\text { Degree of } \\
\text { freedom }\end{array}$ & $\begin{array}{l}\text { Sum of } \\
\text { square }\end{array}$ & $\begin{array}{l}\text { Mean } \\
\text { square }\end{array}$ & $\begin{array}{l}\text { Expected mean } \\
\text { square }\end{array}$ \\
\hline Block & $\mathrm{r}-1$ & $\mathrm{SS}_{\mathrm{B}}$ & $\mathrm{MS}_{\mathrm{B}}$ & $\sigma_{\mathrm{E}}^{2}+\mathrm{g} \mathrm{\sigma ^{2 }}{ }_{\mathrm{B}}$ \\
\hline Among line & $\mathrm{g}-1$ & $\mathrm{SS}_{\mathrm{AL}}$ & $\mathrm{MS}_{\mathrm{AL}}$ & $\sigma_{\mathrm{E}}^{2}+\mathrm{r} \sigma^{2}{ }_{\mathrm{G}}$ \\
\hline Within line & $(\mathrm{r}-1)(\mathrm{g}-1)$ & $\mathrm{SS}_{\mathrm{WL}}$ & $\mathrm{MS}_{\mathrm{WL}}$ & $\sigma_{\mathrm{E}}$ \\
\hline Error & $\mathrm{rg}(\mathrm{s}-1)$ & $\mathrm{SS}_{\mathrm{E}}$ & $\mathrm{MS}_{\mathrm{E}}$ & $\sigma_{\mathrm{S}}$ \\
\hline
\end{tabular}

$$
\sigma 2 \mathrm{E}=\mathrm{MS} \text { within line }
$$

$$
\sigma 2 \mathrm{G}=(\mathrm{MS} \text { among line }-\mathrm{MS} \text { within line }) / 7
$$$$
\sigma 2 \mathrm{P}=\sigma 2 \mathrm{G}+\sigma 2 \mathrm{E}
$$

where $\sigma_{\mathrm{E}}^{2}$ : environmental variance, $\sigma_{\mathrm{G}}^{2}$ : genotypic variance, and $\sigma_{\mathrm{P}}^{2}$ : phenotypic variance. 
The phenotypic and genotypic coefficient of variations were estimated using the formula suggested by [19] given as:

$$
\begin{aligned}
\mathrm{PCV} & =\sqrt{\sigma_{\mathrm{P}}^{2}} / \overline{\mathrm{X}} \times 100 \% \\
\mathrm{GCV} & =\sqrt{\sigma_{\mathrm{G}}^{2}} / \overline{\mathrm{X}} \times 100 \%
\end{aligned}
$$

where PCV: phenotypic coefficient of variation, GCV: genotypic coefficient of variation, and $\overline{\mathrm{X}}$ : the general mean of the corresponding trait.

Broad-sense heritability was estimated following [20] as

$$
\mathrm{h} 2 \mathrm{~B}=\sigma 2 \mathrm{G} / \sigma 2 \mathrm{P}
$$

where $\mathrm{h}_{\mathrm{B}}^{2}$ is classed as low $(<30 \%)$, moderate $(30-60 \%)$, and high $(>60 \%)$.

The genetic advances were predicted using the formula given by [21] as:

$$
\begin{gathered}
\mathrm{GA}=\mathrm{i} \cdot \sqrt{\sigma_{\mathrm{P}}^{2}} \cdot \mathrm{h} 2 \mathrm{~B} \\
\mathrm{GAM}=\mathrm{GAM}=\mathrm{GA} / \overline{\mathrm{X}} \times 100 \%
\end{gathered}
$$

where GA: genetic advance, GAM: genetic advance as a percentage of the trait grand mean, $\mathrm{i}=2.063$ for $5 \%$ selection intensity. GAM is classed as low $(<10 \%)$, moderate $(10-$ $20 \%)$, and high (>30\%).

\section{RESULTS AND DISCUSSION}

\section{A. Variability of the population}

The overall performances of the population under study were shown in Table 3. Mean and range values, along with their coefficient of variation (CV), indicated the existence of considerable variability in the population for most of the traits with stalk diameter being the highest. Such features provide an initial signal that the population consisted of a wide range of plant types to warrant a large scope and flexibility for practicing selection based on the phenotypic performances. The mean squares derived from analysis of variance (Table 4) revealed significant genotypic effects among the lines and shared the largest portions of the total variability of all traits. These confirmed that the examined lines were readily exploitable for improvement through selection. The existence of high significant within-line variation for most traits, excepting stalk diameter, indicated that plant-to-plant uniformity within each line had not been reached. The genetic materials used in this study were S5 generations, and, theoretically, they should have been nearly homozygous in most of the linked loci [22] to produce more homogeneous phenotypes within each line [23].

Nevertheless, a continued inbreeding process is required to bring the lines into highly inbred and homozygous in all loci. Spatial variability in soil fertility could also be a possible explanation for such plant-to-plant variations. A study conducted by [24] showed that the distribution of fertility in organic soil was heterogeneous with an irregular pattern.
TABLE III

OVERALl PERFORMANCES OF EIGHT SWEET CORN INBRED LINES AS GROWN UNDER ORGANIC CROPPING SYSTEM

\begin{tabular}{|l|c|c|c|c|}
\hline \multicolumn{1}{|c|}{ Trait } & Minimum & Maximum & Mean & CV (\%) \\
\hline $\begin{array}{l}\text { Plant height } \\
(\mathrm{cm})\end{array}$ & 2.38 & 255 & 202.19 & 10.07 \\
\hline $\begin{array}{l}\text { Number of } \\
\text { leaves }\end{array}$ & 9 & 14 & 11.77 & 7.87 \\
\hline $\begin{array}{l}\text { Stalk diameter } \\
(\mathrm{cm})\end{array}$ & 1.3 & 2.9 & 2.36 & 18.84 \\
\hline Ear length (cm) & 19.5 & 39 & 28.10 & 10.08 \\
\hline $\begin{array}{l}\text { Ear diameter } \\
\text { (mm) }\end{array}$ & 37.14 & 69.29 & 52.63 & 8.05 \\
\hline Kernel-row No & 10 & 19 & 14.07 & 10.09 \\
\hline $\begin{array}{l}\text { Kernel no. per } \\
\text { row }\end{array}$ & 19 & 50 & 30.19 & 15.63 \\
\hline $\begin{array}{l}\text { Ear yield per } \\
\text { plant (g) }\end{array}$ & 122 & 426 & 252.43 & 17.96 \\
\hline
\end{tabular}

\section{B. Mean Performances of the Lines}

The mean values depicted in Fig. 1 to Fig. 3 indicated that the inbred lines varied substantially in the growth performances and readily exploited for particular breeding programs, such as improved biomass for Stover silage, sugar, and bioethanol productions [25, 26]. Within this context, CAPS 2 was identified as the best lines for distinctively exhibiting the tallest stature, the largest number of leaves, and larger stalk diameter. A path analysis carried out by [27] indicated that plant height and stalk diameter had a positive direct contribution to ear yield by $31.0 \%$ and $17.7 \%$, respectively, implying that both traits had an amenable role in the plant yield. A closer inspection of the remaining lines, it was revealed that CAPS 3 , CAPS 17 , could serve as alternative lines to CAPS2.

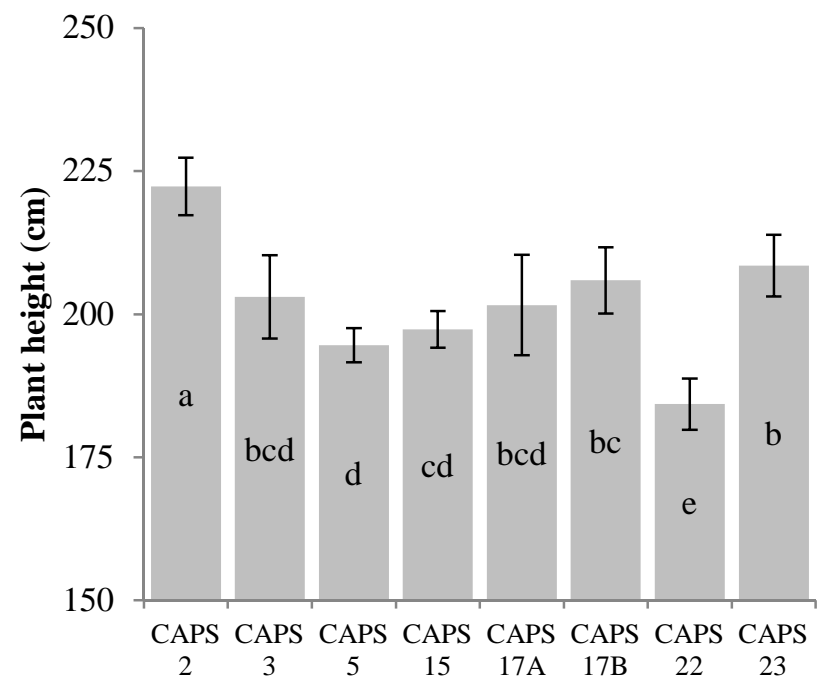

Fig. 1 Mean values of plant height row in 8 sweet corn inbred lines as tested using $\mathrm{LSD}$ at $\mathrm{P}<0.05$ 
TABLE IV

MEAN SQuARES FROM ANALYSIS OF VARIANCE FOR EIGHT TRAITS IN EIGHT INBRED LiNE AS GROWN UNDER ORGANIC CROPPING SYSTEM

\begin{tabular}{|c|c|c|c|c|c|c|c|c|c|}
\hline Source & df & $\begin{array}{l}\text { Plant } \\
\text { height }\end{array}$ & $\begin{array}{l}\text { Number } \\
\text { of leaves }\end{array}$ & $\begin{array}{c}\text { Stem } \\
\text { diameter }\end{array}$ & $\begin{array}{c}\text { Ear } \\
\text { length }\end{array}$ & $\begin{array}{c}\text { Ear } \\
\text { diameter }\end{array}$ & $\begin{array}{l}\text { Kernel- } \\
\text { row no. }\end{array}$ & $\begin{array}{c}\text { Kernel } \\
\text { no. per } \\
\text { row }\end{array}$ & $\begin{array}{l}\text { Ear yield } \\
\text { per plant }\end{array}$ \\
\hline Block & 6 & 1016.98 & 0.36 & 3.73 & 10.05 & 62.97 & 4.45 & 10.96 & 9985.16 \\
\hline Among line & 7 & $4305.77^{*}$ & $6.79^{* *}$ & $9.44^{* *}$ & $281.46^{* *}$ & $326.59^{* *}$ & $10.87^{* *}$ & $275.97^{* *}$ & $59998.76^{* * *}$ \\
\hline Within line & 42 & $1636.07^{* *}$ & $1.53^{* *}$ & 2.37 & $22.69^{* *}$ & $46.70^{* * *}$ & $3.48^{* *}$ & $61.26^{* *}$ & $4862.82^{* *}$ \\
\hline Error & 224 & 414.28 & 0.86 & 1.92 & 8.03 & 17.93 & 2.02 & 22.28 & 2055.00 \\
\hline
\end{tabular}

* and ** significant at $\mathrm{P}<0.05$ and $\mathrm{P}<0.01$, respectively

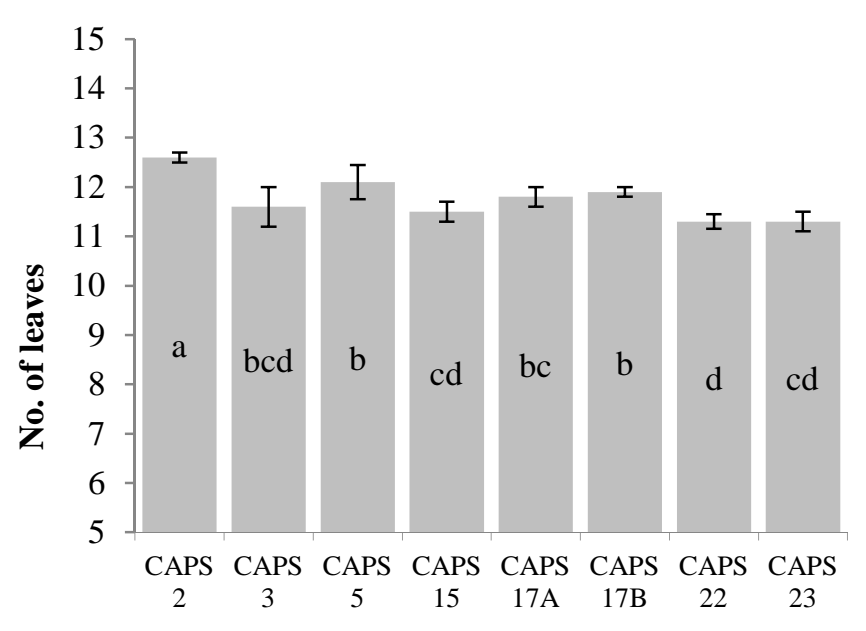

Fig. 2 Mean values of 8 sweet corn inbred lines for the number of leaves as tested using LSD at $\mathrm{P}<0.05$

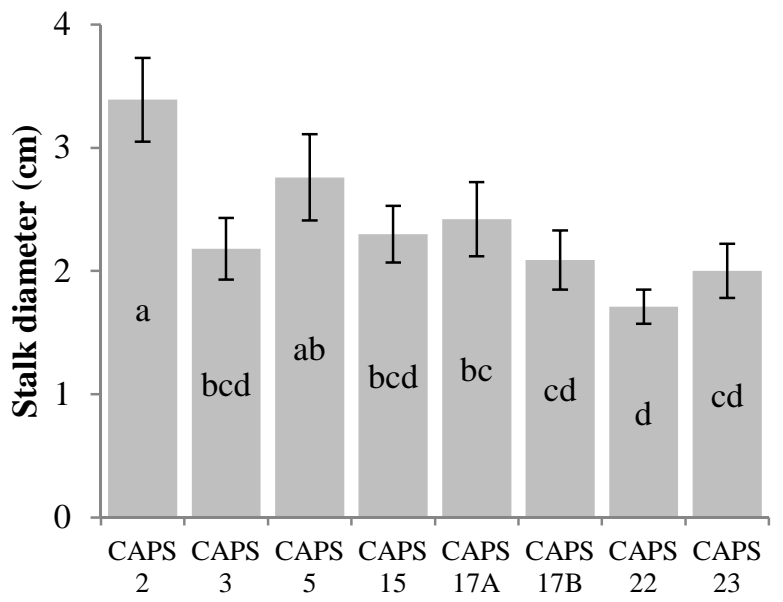

Fig. 3 Mean values of 8 sweet corn inbred lines for the number of leaves as tested using LSD at $\mathrm{P}<0.05$

Fig. 4 to Fig. 7 displays the mean performances for yield and its related components of the inbred lines. In reference to ear yield per plant, CAPS 5 was identified as a superior line, followed by CAPS 2, CAPS 3, CAPS 17A, and CAPS 17B. CAPS 5 was also characterized by high ear diameter, kernel-row number, and kernel number per row. These results suggested a strong indication that CAPS 17A, CAPS 2, CAPS3, CAPS 5, and CAPS 17B could serve as potential parents for improving growth performances and plant yield.

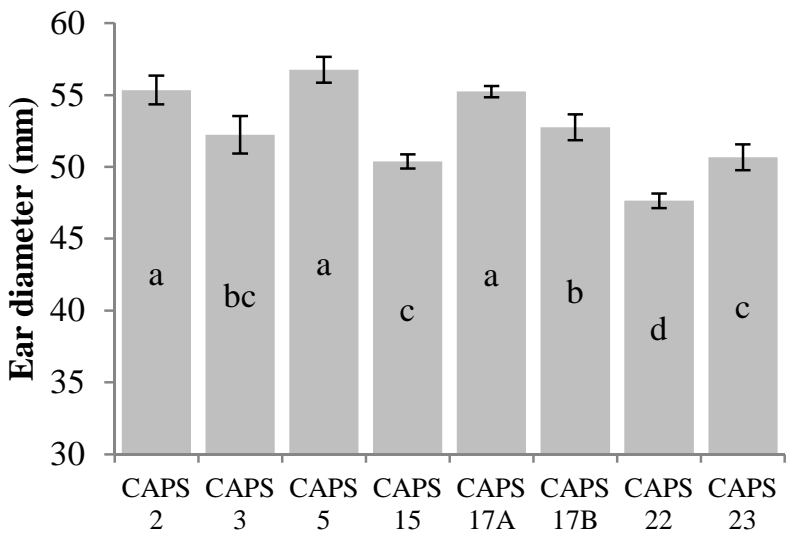

Fig. 4 Mean values of ear diameter in 8 sweet corn inbred lines as tested using LSD at $\mathrm{P}<0.05$

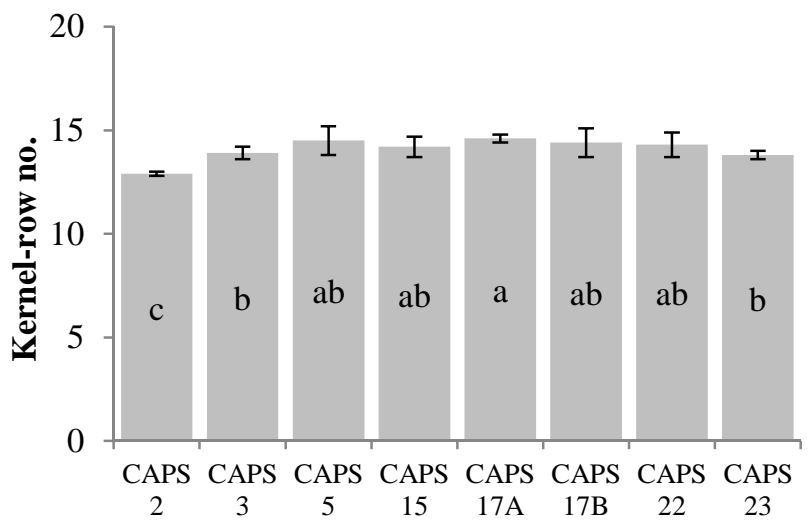

Fig. 5 Mean values of kernel-row number in 8 sweet corn inbred lines as tested using LSD at $\mathrm{P}<0.05$

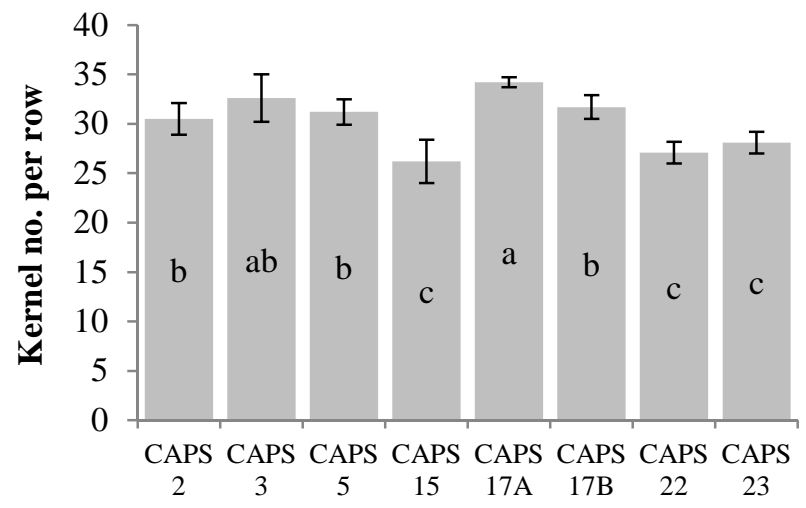

Fig 6. Mean values of kernel number per row in 8 sweet corn inbred lines as tested using LSD at $\mathrm{P}<0.05$ 


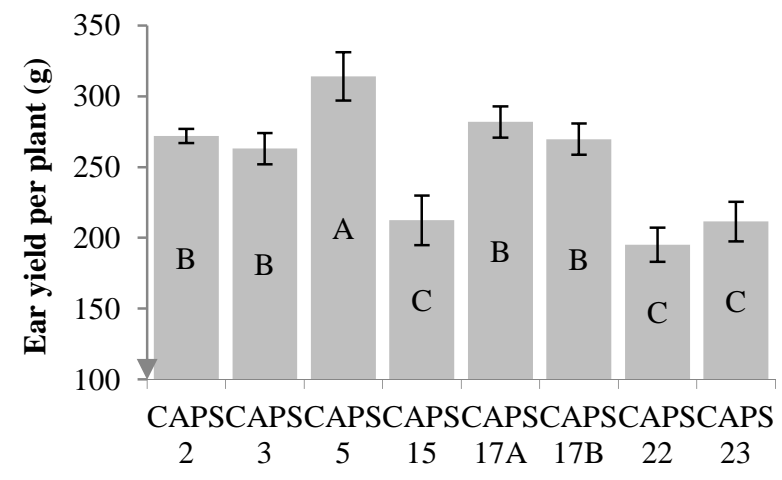

Fig. 7 Mean values of ear yield per plant in 8 inbred corn lines as tested using LSD at $\mathrm{P}<0.05$

\section{The Estimate of genetic parameters}

Table 5 presents the genetic parameters estimated for all traits studied. The highest phenotypic coefficient of variation (CVP) and genotypic coefficients of variation (CVG) was recorded on stalk diameter, as followed by ear yield per plant. The rest of the traits had low to moderate CVP with low CVG. In all cases, the magnitudes of CVP) were larger than the corresponding $\mathrm{CVG}$ with the sizeable difference between them. The difference between CVP and CVG indicates the sensitivity to environmental fluctuations [28]; the wider the difference implies that the traits would be more sensitive to environmental variability, and vise-versa.

TABLE V

GENETIC PARAMETERS ESTIMATED FROM EIGHT TRAITS IN EIGHT INBRED LINES AS GROWN UNDER AN ORGANIC CROPPING SYSTEM

\begin{tabular}{|l|c|c|c|c|c|}
\hline Trait & CVP $(\%)$ & CVG $(\%)$ & $\mathrm{H}^{2}{ }_{\mathrm{B}}$ & GA & GAM (\%) \\
\hline Plant Height & 13.21 & 5.08 & 0.15 & 8.17 & 4.04 \\
\hline Number of leaves & 9.03 & 3.47 & 0.15 & 0.32 & 2.74 \\
\hline Stalk diameter & 63.02 & 19.57 & 0.10 & 0.30 & 12.54 \\
\hline Ear length & 15.14 & 9.90 & 0.43 & 3.76 & 13.37 \\
\hline Ear diameter & 10.61 & 5.60 & 0.28 & 3.21 & 6.10 \\
\hline Kernel row no. & 11.22 & 3.53 & 0.10 & 0.32 & 2.29 \\
\hline Kernel no. per row & 19.74 & 8.81 & 0.20 & 2.45 & 8.11 \\
\hline Ear yield per plant & 25.49 & 16.06 & 0.40 & 52.67 & 20.86 \\
\hline
\end{tabular}

The estimate of broad-sense heritability $\left(\mathrm{H}^{2}{ }_{\mathrm{B}}\right)$ denotes the relative contribution of the heritable portion of a trait variability and provides measures to the plant breeder in deciding the optimal selection strategies under a given environment [29]. The broad-sense heritability across traits was ranged from low to moderate $\left(0.10<\mathrm{H}^{2}{ }_{\mathrm{B}}<0.43\right)$, with the highest estimate, which was recorded on ear length. In the previous study, higher $\mathrm{H}^{2}$ B estimates were reported for most of the traits currently studied [30]. This disagreement was not surprising as $\mathrm{H}_{\mathrm{B}}^{2}$ is not only the property of the trait being studied but also the population being sampled in each environment [31].

The estimate of genetic advance (GA) measures the expected gain from selecting the best performance genotypes for a given trait [32]. The range of GA varied from 0.30 to 52.67. The highest GA was observed on-ear yield per plant (52.67), whereas the lowest GA was observed on stalk diameter (0.30). GA values of different traits are not comparable due to a unit of measurement dependency. To facilitate comparison in the selection gain among different traits, GA expressed as genetic advance as percent of the population mean (GAM) is commonly preferred. Ear yield per plant showed the highest GAM (20.86\%), indicating that a sizeable yield improvement could be gained by selecting the top $5 \%$ of the breeding population. By applying the same selection pressure, notable improvements could also be expected for stalk diameter $(12.54 \%)$ and ear length $(13.37 \%)$. The rest of the traits would have slow selection progress, as indicated by low GAM $(<10 \%)$.

Combining information gained from $\mathrm{H}^{2}{ }_{\mathrm{B}}$ and GAM would reveal the mode of inheritance for a given trait [33] and, in turn, they would affirm the selection strategy to be implemented. In the present study, moderate $\mathrm{H}^{2}$ B coupled with moderate GAM were observed on ear length and ear yield per plant, indicating that both additive and nonadditive gene actions controlled the expression of the traits. The remaining traits had low $\mathrm{H}^{2}$ Bith low GAM, indicating that expression of these traits was prominently controlled by non-additive gene action. Having known that non-additive gene action was predominant in governing the expression for most of the desired traits, a recurrent selection system should be considered for their improvement in the successive generations [34], [35].

\section{CONCLUSION}

Considerable variations in yield and its related traits were observed to warrant further improvement of the sweet corn breeding materials. CAPS 17A, CAPS 2, CAPS3, CAPS 5, and CAPS 17B were identified as potential inbred lines for utilization in developing new sweet corn varieties better adapted for organic environment. Elucidation of the genetic merit of variations, however, indicated that selection progress could be hindered by the involvement of non-additive genes and great environmental influence. Recurrent selection, therefore, was considered to be the most appropriate method for improving overall plant performances. 


\section{ACKNOWLEDGMENT}

We gratefully acknowledge the financial support awarded by the University of Bengkulu for running this research project.

\section{REFERENCES}

[1] A. Efthimiadou, D. Bilalis, A. Karkanis, B. Froud-Williams, and I Eleftherochorinos. "Effects of the cultural system (organic and conventional) on growth, photosynthesis and yield components of sweet corn (Zea mays L.) under semi-arid environment" Notulae Botanicae Horti Agrobotanici Cluj-Napoca vol. 37, pp 104-111, 2009.

[2] C. Lazcano, M. Gómez-Brandón, P. Revilla, and J. Domínguez. "Short-term effects of organic and inorganic fertilizers on soil microbial community structure and function" Biology and Fertility of Soils vol. 49, pp 723-733, 2013.

[3] K. Murmu, D.K., Swain, and B.C. Ghosh. "Comparative assessment of conventional and organic nutrient management on crop growth and yield and soil fertility in tomato-sweet corn production system" Australian Journal of Crop Science vol. 7, pp 1617-1626, 2013.

[4] A.W. Johnson and R.B. Chalfant. "Influence of organic pesticides on nematode and corn earworm damage and on yield of sweet corn" Journal of Nematology vol. 5, pp 177-180, 1973.

[5] C.G. Summers and J.J. Stapleton. "Management of corn leafhopper (Homoptera: Cicadellidae) and corn stunt disease in sweet corn using reflective mulch" Journal of economic entomology vol. 95, pp 325330, 2002.

[6] M.A. Altieri and C.I. Nicholls. "Soil fertility management and insect pests: harmonizing soil and plant health in agroecosystems" Soil and Tillage Research vol. 72, pp 203-211, 2003.

[7] P. Revilla, J.I.R. de Galarreta, R.A. Malvar, A. Landa, and A. Ordás. "Breeding maize for traditional and organic agriculture" Euphytica vol. 205, pp 219-230, 2015.

[8] G.E. Boyhan and S.P. Stone. "Breeding for Organic and Sustainable Production" Organic Farming for Sustainable Agriculture vol. 9, pp 123-136, 2016

[9] W.F. Tracy. "Potential of field corn germplasm for the improvement of sweet corn" Crop Sci. vol. 30, pp 1041-1045, 1990.

[10] M.E. Cartea, R.A. Malvar, P. Revilla, and A. Ordas. "Identification of field corn populations to improve sweet corn for Atlantic European conditions" Crop Sci. vol. 36, pp 1506-1512, 1996.

[11] J. Laffan. "Organic farming: An introduction" NSW Department of Primary Industry, New South Wales, 2016.

[12] E.L. van Bueren, S.S. Jones, L. Tamm, K.M. Murphy, J.R. Myers, C. Leifert, and M.M. Messmer. "The need to breed crop varieties suitable for organic farming, using wheat, tomato and broccoli as examples: a review" NJAS-Wageningen Journal of Life Sciences vol 58, pp 193-205, 2011.

[13] L.F. Bauman. "Review of methods used by breeders to develop superior corn inbreds" in Proc. The Annual Corn and Sorghum Ind. Res. Conf. 36, pp 199 -208, 1981.

[14] F.J. Betrán, M. Menz, and M. Bänziger. "Corn breeding” In C.W. Smith, F.J. Betrán, and E.C.A. Runge (eds). Hoboken, NJ: John Wiley \& Sons, 2004.

[15] Z. Muktamar, N. Setyowati, S. Sudjatmiko, and M. Chozin. "Selected macronutrient uptake by sweet corn under different rates of liquid organic fertilizer in closed agriculture system" IJASEIT vol 6, pp 258-261, 2016.

[16] Fahrurrozi, Z. Muktamar, N. Setyowati, S. Sudjatmiko, and M. Chozin. "Growth and yield responses of three sweet corn (Zea mays L. var. Saccharata) varieties to local-based liquid organic fertilizer" IJASEIT vol 6, pp 319-323, 2016.

[17] R.G.D. Steel and J.H. Torrie. Principles and Procedures of Statistics: A Biometrical Approach. New York: McGraw-Hill, 1980.

[18] W.A. Becker. Manual of Quantitative Genetics. Pullman, WA, U.S.A.: Academic Enterprises, 1992

[19] R.K. Singh and B.D. Chaudhary. Biometrical Methods in Quantitative Genetics Analysis. New Delhi-Ludhiana: Kalyani Publishers, 1985.

[20] D.S. Falconer and T. F. C. Mackay. Introduction to Quantitative Genetics, $4^{\text {th }}$ ed. Harlow, Essex, UK: Longmans Green, 1996.

[21] H.W. Johnson, H.F. Robinson, and R.E. Comstock. "Estimate of genetic and environmental variability in soybean." Agron. J. vol 47, pp 314-318. (1955).

[22] I. Bos and P. Caligari Selection Methods in Plant Breeding, $2^{\text {nd }}$. Dordrecht, The Netherlands: Springer Science \& Business Media, 2008.

[23] G. Acquaah. Principles of Plant Genetics and Breeding, $2^{\text {nd }}$ ed. West Sussex, UK: John Wiley \& Sons, 2012.

[24] C.A. Cambardella and D.L. Karlen. "Spatial analysis of soil fertility parameters" Precision Agriculture vol. 1, pp 5-14, 1999.

[25] A.B. Idris, S.M. Yusoff, and A. Sharif. "Sweet corn stover silage production" Fao Plant Production and Protection Papers, pp 107-108, 2000.

[26] J. Barros-Rios, A. Roman, G., Garrote, and B. Ordas." Biomass, sugar, and bioethanol potential of sweet corn" Gcb Bioenergy vol 7 , pp 153-160, 2015.

[27] Oktem, A. (2008). Determination of selection criterions for sweet corn using path coefficient analyses. Cereal Research Communications, 36(4), 561-570.

[28] S.K. Jain, P.R. Patel, and M Elangovan. "Variation and association among fodder yield and other traits in germplasm of forage sorghum (Sorghum bicolor (L.) Moench)" Indian J. Plant Genet. Resour. vol. 24, pp 327-331, 2011.

[29] J.B. Holland, W.E. Nyquist, and C.T. Cervantes-Martínez. "Estimating and interpreting heritability for plant breeding: An update" Plant Breeding Reviews vol. 22, pp 9-112, 2003.

[30] P. Kashiani, G. Saleh, N.A.P. Abdullah, and S.N. Abdullah. "Variation and genetic studies on selected sweet corn inbred lines" Asian J. Crop Sci. vol. 2, pp 78-84, 2010.

[31] A.R. Dabholkar. Elements of Bio Metrical Genetics (Revised and Enlarged Edition). New Delhi: Concept Publishing Co., 1999.

[32] R.W. Allard. Principles of Plant Breeding. $2^{\text {nd }}$ ed. New York, NY: John Wiley \& Sons, 1999.

[33] J.W. Dudley and R. H. Moll. "Interpretation and use of estimates of heritability and genetic variances in plant breeding." Crop Science vol. 9, pp 257-262, 1969.

[34] A.R. Hallauer, J. Marcelo. J.B. Carena, and F. Miranda. Quantitative Genetics in Maize Breeding. New York: Springer, 2010.

[35] L.R.D.S. Camacho, C.A. Scapim, H.J.C. Senhorinho, and T.V. Conrado. "Diallel analysis of popcorn lines and hybrids for baby corn production" Crop Breeding and Applied Biotechnology vol. 15, pp 33-39, 2015. 